\title{
Flood-Inundation Mapping for the Blue River and Selected Tributaries in Kansas City, Missouri, and Vicinity, 2012
}

\section{Overview}

Kansas City, Missouri, has severely flooded many times, most notably in 1951, 1961, 1977, 1984, 1990, 1998, and 2010 (National Oceanic and Atmospheric Administration, National Weather Service, 2014). During the past 30 years these floods resulted in damages within Kansas City costing tens of millions of dollars and more than 25 casualties (U.S. Army Corps of Engineers, 1967; Hauth and Carswell, 1981).

The U.S. Geological Survey (USGS) and City of Kansas City, Missouri, operate multiple streamgages along the Blue River and tributaries in and near the city. Knowledge of water level at a streamgage is difficult to translate into depth and areal extent of flooding at points distant from the streamgage. One way to address these informational gaps is to produce a library of flood-inundation maps that are referenced to the stages recorded at a streamgage. By referring to the appropriate map, emergency responders can discern the severity of flooding (depth of water and areal extent), identify roads that are or may be flooded, and make plans for notification or evacuation of residents in harm's way for some distance upstream and downstream from the streamgage. The USGS, in cooperation with the city of Kansas City, Missouri, developed a library of flood-inundation maps for the Blue River and selected tributaries.

\section{Creation of Flood-Inundation-Map Library}

\section{Computation of Water-Surface Profiles}

Water-surface profiles showing the distribution of streamflow for a range of stage-flow conditions in 15 mapped reaches along the Blue River and selected tributaries (fig. 1) were simulated using one-dimensional (HEC-RAS, version 4.1; U.S. Army Corps of Engineers, 2010) or two-dimensional 


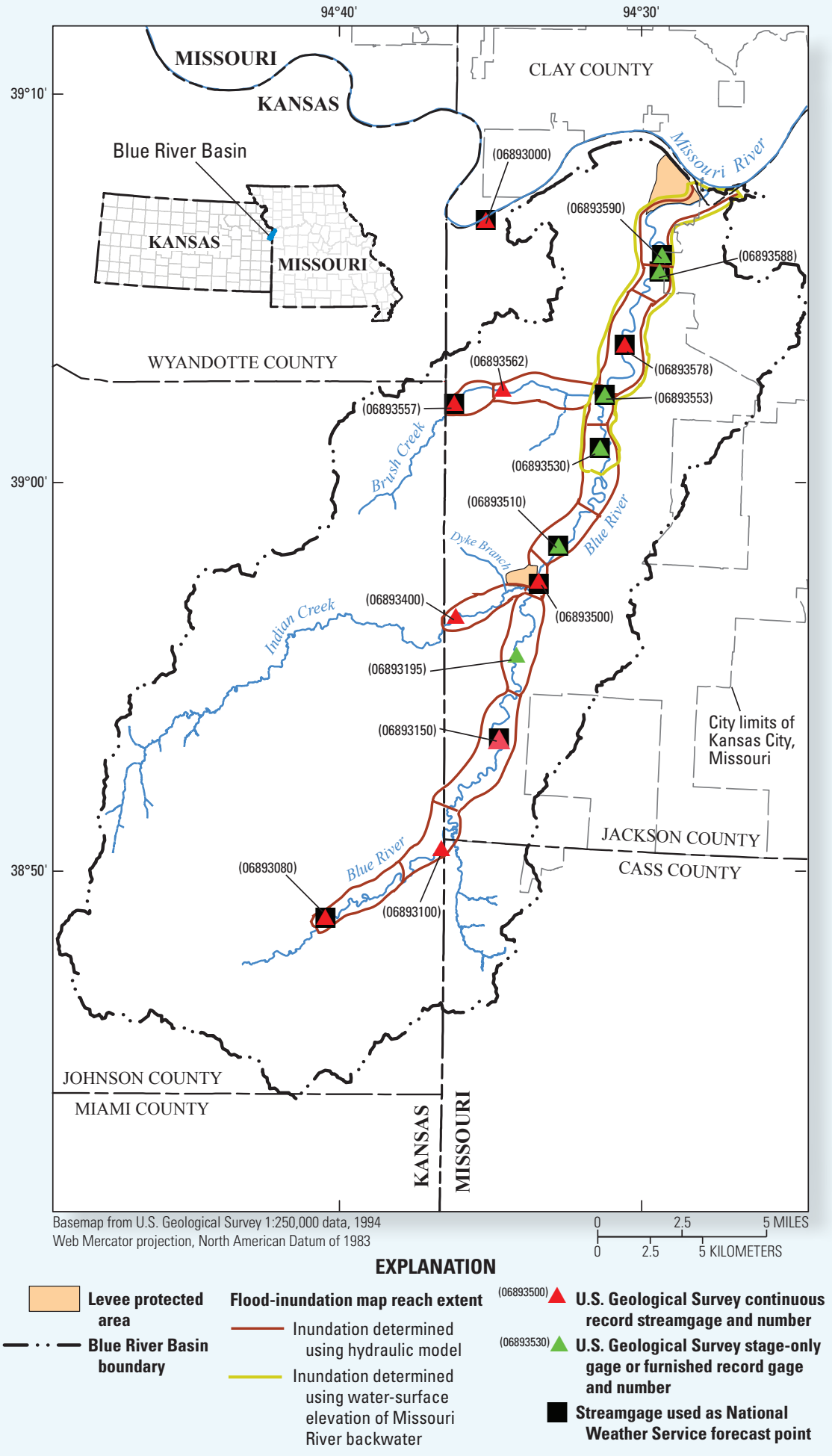

Figure 1. Site map of Blue River and tributary flood-inundation map reaches and streamgages.

(FST2DH, release 3.3.3; Froehlich, 2003) steady-state hydraulic models. Results in Heimann and others (2014) update and increase the resolution of inundation maps produced by Kelly and Rydlund, (2006) and Kelly and Huizinga (2008) and account for Blue River channel modifications (widen, deepen, and straighten channel) completed by the U.S. Army Corps of Engineers in 2010 to increase channel conveyance in the lower Blue River Basin (fig. 2).

\section{Hydrologic Data}

The study-area hydrologic network consists of 15 streamgages (figs. 1 and 3). Continuous stream stage generally is measured every 15 minutes, transmitted hourly by a satellite radio in the streamgage, and made available on the Internet through the USGS National Water Information System (NWIS; U.S. Geological Survey, 2014a). The stage-streamflow ratings from nine streamflow-gaging stations and documented high-water marks (Donald Wilkison, U.S. Geological Survey, written commun., 2013) from the June 14, 2010, flood were used in the calibration of the hydraulic models.

\section{Hydraulic Models}

Steady-state flow data consisted of flow regime, boundary conditions, and peak flows that produced water-surface elevations at the streamgage cross section that matched target water-surface elevations. Flood-inundation maps were produced for even 1-ft increments of stage that were referenced to the local streamgage datum; the target elevations ranged from about bankfull to the stage corresponding to the 0.2-percent annual exceedance probability flow (equivalent to a 500-year recurrence interval flow). Model calibration was done by adjusting roughness coefficients (Manning's n values) until the results of the hydraulic computations closely agreed with the observed water-surface elevations or stages from the coinciding stage-streamflow rating.

\section{Development of Flood-Inundation Maps}

Flood-inundation maps were created in a geographic information system (GIS) by combining simulated water-surface profiles and terrain elevation data (fig. 4). The terrain model data were derived from lidar data and stream channel and bridge surveys at selected locations. Estimated flood-inundation boundaries for each simulated profile in HEC-RAS were developed with HECGeoRAS software (U.S. Army Corps of Engineers, 2009), which allows the preparation of geometric data for import into HEC-RAS and processes simulation results exported from HEC-RAS (U.S. Army Corps of Engineers, 2010).

\section{Flood-Inundation Map Delivery}

A Flood-Inundation Mapping Science Web site (http:// water.usgs.gov/osw/flood_inundation/; U.S. Geological Survey, 2014b) has been established to make USGS flood-inundation study information available to the public (fig. 5). The site links to a mapping application that presents map libraries and provides detailed information on flood extents and depths for modeled sites. The mapping application enables the production of customized flood-inundation maps from the map library for the 


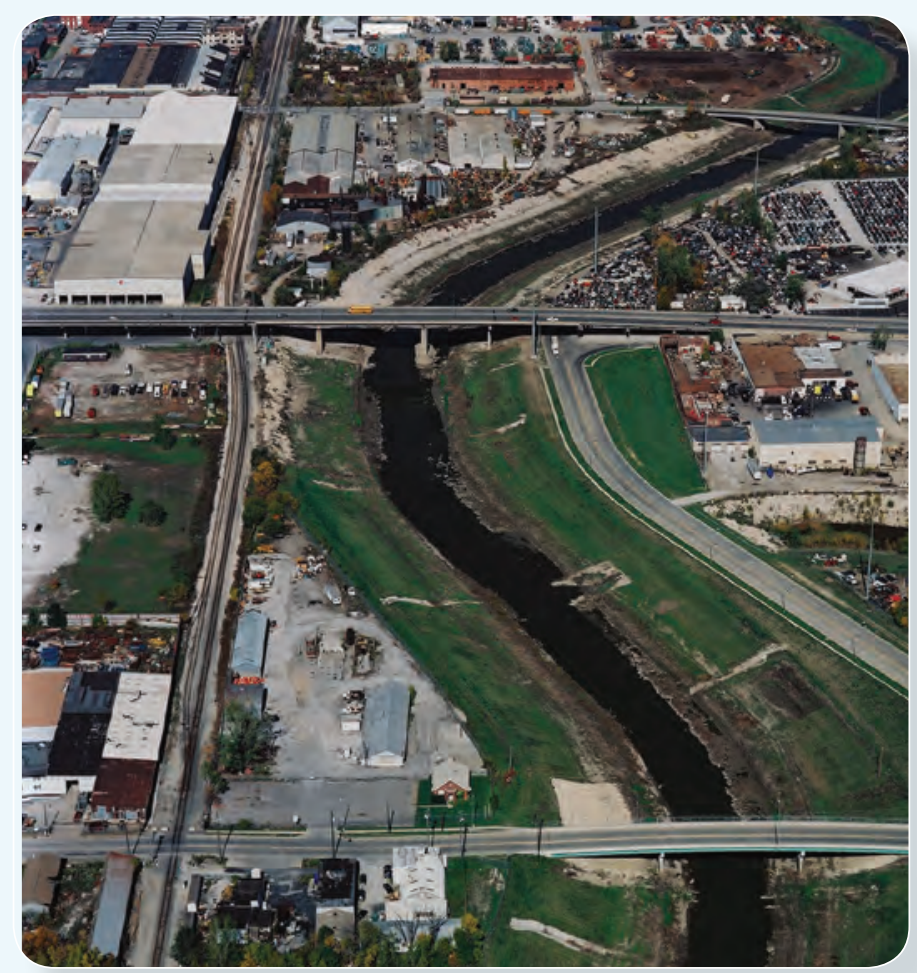

Figure 2. Channel modifications along the lower Blue River in Kansas City, Missouri.

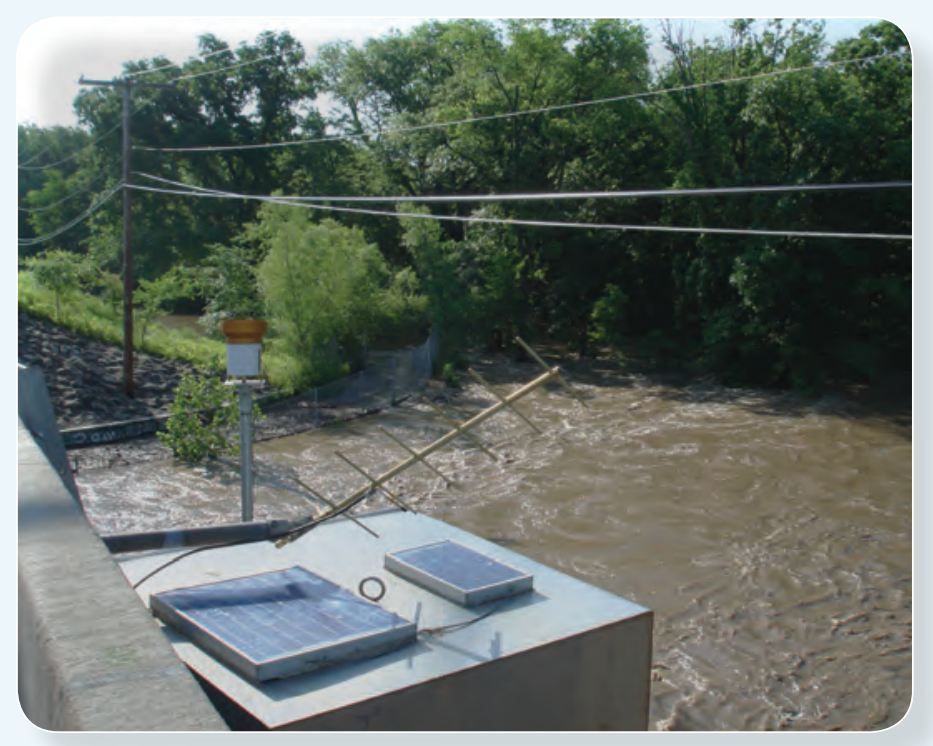

Figure 3. U.S. Geological Survey streamgage at the Blue Ridge Boulevard Extension, Kansas City, Missouri.

15 study reaches. A link on this Web site connects to the USGS NWIS, which presents the current stage and streamflow at the USGS streamgages to which the inundation maps are referenced. A second link connects to the National Weather Services Advanced Hydrologic Prediction Service (AHPS) Web site (National Oceanic and Atmospheric Administration, National Weather Service, 2014) so that the user can obtain applicable information on forecasted peak stage at forecast points. The estimated flood-inundation maps are displayed in sufficient detail so managers can respond efficiently to flooding and decisions for emergency response can be made accordingly.

\section{Simulated water-surface profile}

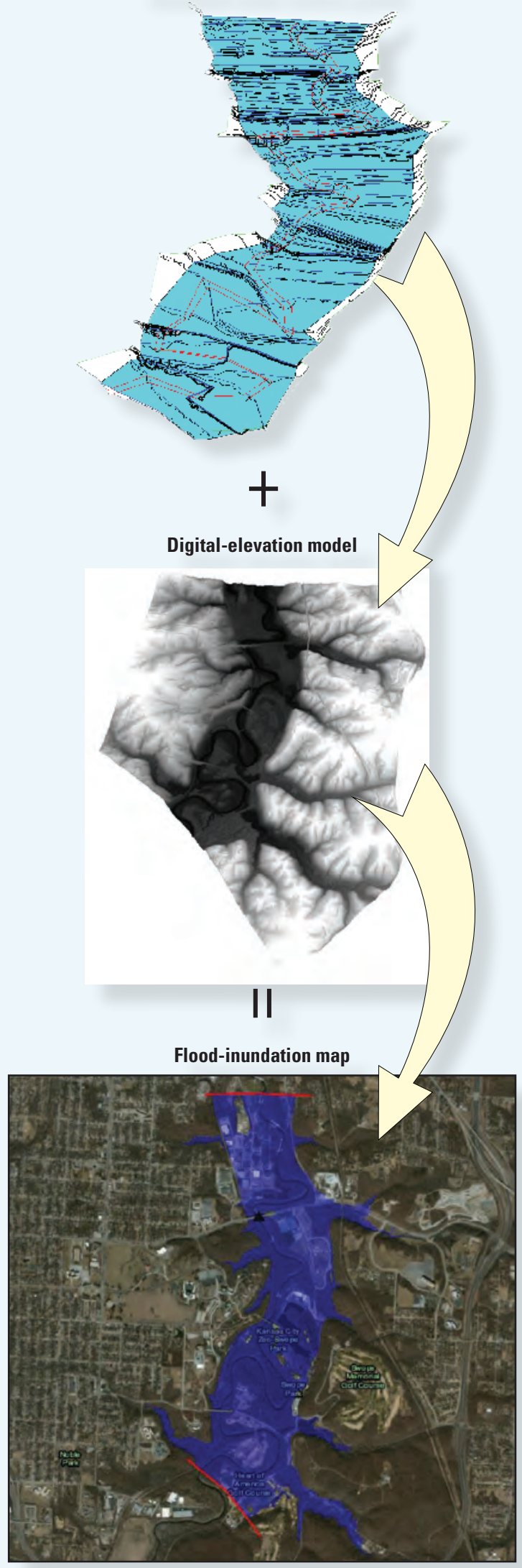

Figure 4. Simulated water-surface profile, digitalelevation model, and developed flood-inundnation map for the Blue River at 63rd Street, Kansas City, Missouri, map reach. 
USGS Real-time streamgage from National Water Information System (NWIS) Web site (U.S. Geological Survey, 2014)

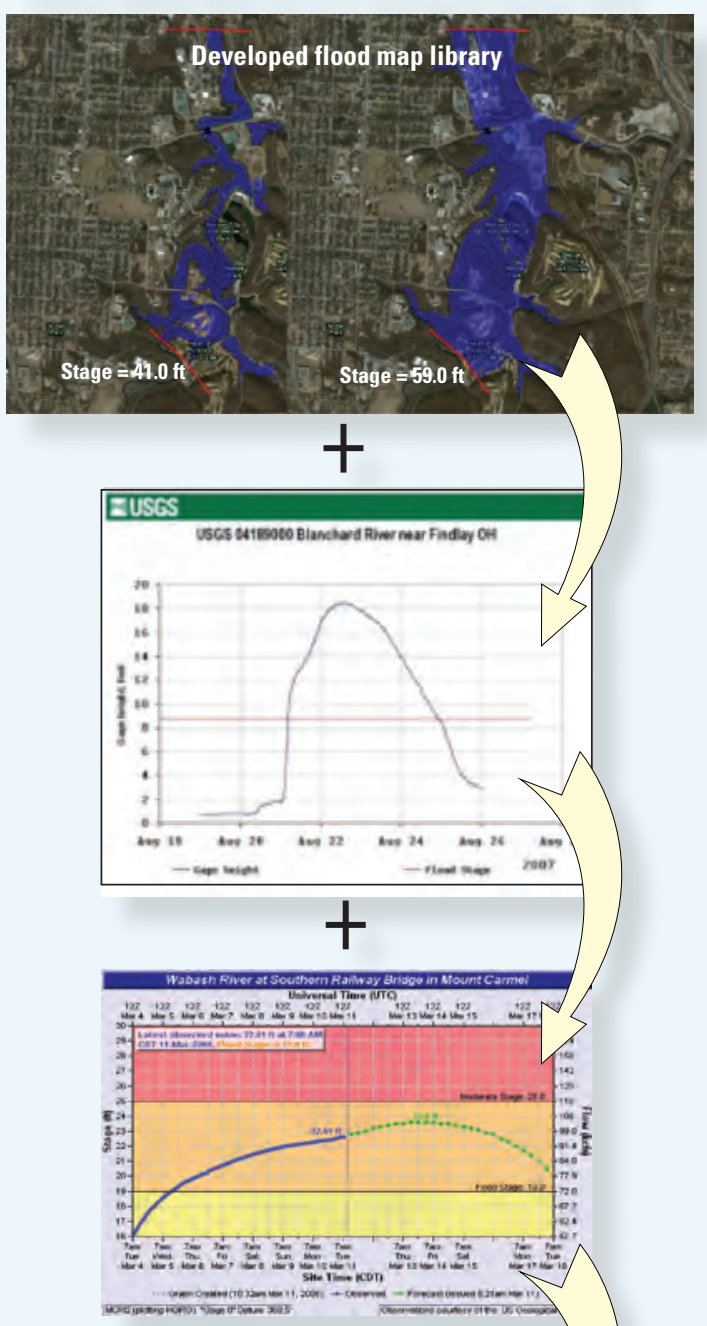

NWS Flood Forecast from AHPS Web site (National Oceanic and Atmospheric Adminstration, National Weather Service, 2014) (Available at selected streamgages)

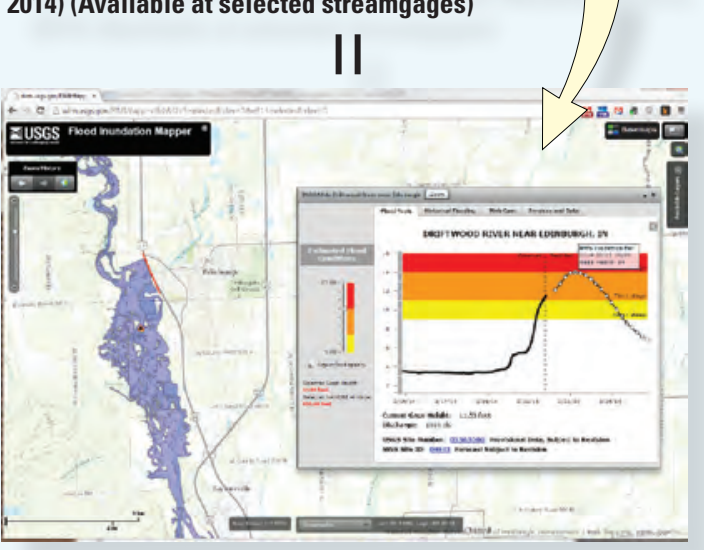

USGS Flood-Inundation Mapper Web site http://wim.usgs.gov/FIMI/

Figure 5. U.S. Geological Survey flood-inundation mapping science Web site components and display.

\section{References Cited}

Froehlich, D.C., 2003, User's manual for FESWMS FST2DHTwo-dimensional depth-averaged flow and sediment transport model: Federal Highway Administration Report No. FHWARD-03-053, [variously paged].
Hauth, L.D. and W.J. Carswell, Jr., 1981, Floods in Kansas City, Missouri and Kansas, September 12-13, 1977: U.S. Geological Survey Professional Paper 1169, 47 p.

Heimann, D.C.,Weilert, T.E., Kelly, B.P., and Studley, S.E., 2014, Flood-inundation maps and Wetland Restoration Suitability Index for the Blue River and selected tributaries, Kansas City, Missouri, and vicinity, 2012: U.S. Geological Survey Scientific Investigations Report 2014-5180, 23 p., http://dx.doi.org/10.3133/ $\operatorname{sir} / 20145180$.

Kelly, B.P., and Rydlund, P.H., Jr., 2006, Estimated flood-inundation mapping for the lower Blue River in Kansas City, Missouri, 2003-05: U.S. Geological Survey Scientific Investigations Report 2006-5089, 27 p.

Kelly, B.P., and Huizinga, R.J., 2008, Estimated flood-inundation mapping for the Upper Blue River, Indian Creek, and Dyke Branch in Kansas City, Missouri, 2006-08: U.S. Geological Survey Scientific Investigations Report 2008-5068, 34 p. plus appendixes.

National Oceanic and Atmospheric Administration, National Weather Service, 2014, Advanced Hydrologic Prediction Service, accessed June 20, 2014, at http://water.weather.gov/ahps/forecasts.php.

South Kansas City Observer, 2010, "More rain overnight leads to (more) southland flooding", accessed September 18, 2014, at http://southkansascityobserver.blogspot.com/2010/06/more-rainovernight-leads-to-more.html.

U.S. Army Corps of Engineers, 1967, Flood plain information, Blue River within Kansas City, Missouri: U.S. Army Corps of Engineers, Kansas City District, 31 p.

U.S. Army Corps of Engineers, Hydrologic Engineering Center, 2009, HEC-GeoRAS, GIS Tools for Support of HEC-RAS using ArcGIS, User's Manual, version 4.2,: Vicksburg, Miss., U.S. Army Corps of Engineers, [variously paged]

U.S. Army Corps of Engineers, Hydrologic Engineering Center, 2010, HEC-RAS River Analysis System, Hydraulic Reference Manual, version 4.1: U.S. Army Corps of Engineers, [variously paged].

U.S. Geological Survey, 2014a, USGS surface-water data for the Nation: U.S. Geological Survey, National Water Information System, accessed June 2014 at http://waterdata.usgs.gov/nwis/sw.

U.S. Geological Survey, 2014b, USGS Flood Inundation Mapping Science: U.S. Geological Survey, accessed June 2014 at http:// water.usgs.gov/osw/flood_inundation.

$$
\begin{aligned}
& \text { By David C. Heimann1, Trina E. Weilert' }{ }^{2} \text { Brian P. Kelly }{ }^{1} \text {, } \\
& \text { and Seth E. Studley }{ }^{1} \\
& { }^{1} \text { U.S. Geological Survey } \\
& { }^{2} \text { Currently U.S. Department of Agriculture, formerly } \\
& \text { U.S. Geological Survey }
\end{aligned}
$$

For more information concerning this publication, contact: Director, Missouri Water Science Center

U.S. Geological Survey

1400 Independence Road, MS-100

Rolla, MO 65401

(573) 308-3667

\section{Or visit the Missouri Water Science Center Web site at: http://mo.water.usgs.gov/}

Banner photograph credit: http://southkansascityobserver.blogspot. com/2010/06/more-rain-overnight-leads-to-more.html, June 15, 2010. 